\title{
Influence of organic enrichment on the partitioning and bioavailability of cadmium in a microcosm study
}

\author{
Joanna Maloney* \\ Norwegian Institute for Water Research (NIVA), PO Box 173 Kjelsâs, N-0411 Oslo, Norway
}

\begin{abstract}
Interactive processes between organic enrichment and cadmium (Cd) were examined in a microcosm experıment over a $10 \mathrm{wk}$ period. Microcosms were stocked with 4 benthic species: Amphiura filiformis, Amphiura chiajei, Abra alba and Nereis diversicolor. The partitioning of $\mathrm{Cd}$ between the sediment and pore water phases and the subsequent bioaccumulation of $\mathrm{Cd}$ in benthic macrofauna were investigated under different organic enrichment regimes. Additions of Cd without organic enrichment resulted in significant increases in both the sediment and pore water Cd concentrations; the magnitude was much greater in the pore water, with a 3 -fold increase indicating that the pore water phase showed the greatest fractional changes in response to $\mathrm{Cd}$ input. The subsequent bioaccumulation of $\mathrm{Cd}$ to 3 benthic species, Amphiura filiformis, Amphiura chiajei and Abra alba, also increased with this $\mathrm{Cd}$ only treatment, as in the ambient sedimentary environment. Cd additions combined with different organic enrichment regimes of cellulose fibres, sewage and benthic algae, at low and high doses, significantly altered the Cd partitioning in the sedimentary matrix. Both algal treatments and high sewage levels significantly decreased the sediment redox potential, with a corresponding increase in sulfide activity. All organic types reduced pore water Cd concentrations, showing a highly significant organic dosage response. However, Cd bioaccumulation in the 3 benthic species examined showed significant variation between the different types or sources of organic materlal, with an increasing gradient of $\mathrm{Cd}$ bioaccumulation in the sequence: fibres < sewage < algae. The growth response of $N$. diversicolor represented a biological measure of benthic food 'quality' and followed this same increasing trend in response to organic ennchment. Therefore, direct concordance was shown between the effect of organic type on polychaete growth and Cd bioaccumulation, indicating that high quality, potential benthic 'food', such as algae, leads to increased $\mathrm{Cd}$ bioaccumulation. This study demonstrates that organic 'quality' or a related parameter forms a most significant factor in determining $\mathrm{Cd}$ bioaccumulation to the marine benthos, and that some sources of organic enrichment do indeed reduce metal bioaccumulation.
\end{abstract}

KEY WORDS: Cadmium Organic enrichment Pore water Sediment Partitioning - Biovailability Microcosm

\section{INTRODUCTION}

Eutrophication and persistent pollutants have been identified as 2 of the greatest environmental threats to European regional seas (Jonsson et al. 1993). A reduction in both nutrients and the disposal of harmful persistent compounds to marine systems has been proposed to protect such contaminated regions; however,

·E-mail; joanna.maloney@niva.no the present knowledge of possible interactions between these 2 environmental problems is poor. It is possible that, because of the potential of the organic material to concentrate pollutants and the selective feeding behaviour of the benthos, eutrophic conditions may increase the bioavailability of pollutants to benthic organisms. Alternatively, the resulting increase in sediment particulate binding potential may in fact result in reduced interstitial contaminant concentrations, thereby reducing toxicity to benthic fauna. The 
main aim of this study was to elucidate some of the interactive processes between eutrophication and cadmium (Cd) additions in marine benthic ecosystems.

Some heavy metals, especially cadmium, mercury and lead, are currently of particular interest and belong to a sub-class of 'trace metals' which consists of metals without any established biological function, often referred to as non-essential metals. These are amongst the most important contaminants in the aquatic environment (Viarengo et al. 1985). Metal input to the marine ecosystem as a result of human exploitation may be up to 50 times higher than the natural supply via weathering processes (Lithner et al. 1.990), and marine sediments of many urbanized coastlines sequester these trace metals and organic pollutants, sometimes to extremely high levels. This accumulation is due to adsorption processes with various geochemical phases such as hydrous metal oxides, clays and organic material (Oakley et al. 1981). The subsequent bioavailability and toxicity of heavy metals to benthic macrofauna depend on the partitioning of the metals within the sediment/pore water matrix. Recent research has shown that the toxicity of trace metal contaminated sediment to some benthic fauna may be more closely related to the concentration in the interstitial pore water than in the bulk sediment (Swartz et al. 1985, Kemp \& Swartz 1988, Landrum 1989, Green et al. 1993) and that cadmium activity in the pore water is in turn primarily controlled by its interactions with the sediment acid-volatile sulfide (AVS) phase (Di Toro et al. 1990, Green et al. 1993)

Olsson \& Jensen (1975) proposed that an increase in organic matter generated from eutrophication processes will contribute to the dilution and reduced toxicity of pollutants; this proposal forms the basis of the 'biomass dilution hypothesis' (Taylor et al. 1991). However, it is possible that such eutrophic conditions may actually increase the bioavailability of pollutants to benthic organisms as mentioned above. Macrofaunal bioturbation, as experienced under conditions of organic enrichment (Pearson \& Rosenberg 1976), may also change the mobility of divalent metals such as $\mathrm{Cd}$ by alterations to the sediment matrix, resulting in increased solute transport and changes in in situ metal, $\mathrm{O}_{2}$ and $\mathrm{pH}$ profiles (Aller 1983. Aller \& Yingst 1985, Green et al. 1993). An additional variable is the possibility that the binding patterns of trace metals to organic matter may only be indirectly correlated with. organic carbon, for example, some metals such as Cd may also have the capacity to react with phosphate groups in the lipid bilayer of various cell membranes (George \& Viarengo 1984).

This study examined the interactions between different sources of organic material and $\mathrm{Cd}$ in a microcosm system. It focused on the partitioning of $\mathrm{Cd}$ between the sediment and pore water compartments, and the subsequent bioaccumulation of $\mathrm{Cd}$ to benthic macrofauna, in order to test the hypothesis that the type of organic enrichment may affect pore water $\mathrm{Cd}$ concentrations and thus the subsequent bioaccumulation of Cd by the marine benthos

\section{MATERIALS AND METHODS}

Experimental microcosm system. The microcosm system consisted of 24 glass aquaria (length $46.5 \mathrm{~cm}$ width $29 \mathrm{~cm}$, height to outflow $21.5 \mathrm{~cm}$ ), designed with partitions at either end to ensure laminar water flow across the sediment surface. A flow-through water system with header tanks supplied unfiltered seawater continuously at a constant rate of approximately $140 \mathrm{ml}$ $\mathrm{min}^{-1}$ from $60 \mathrm{~m}$ depth at Solbergstrand, Oslofjord, Norway $\left(59^{\circ} 37.73^{\prime} \mathrm{N}, 10^{\circ} 38.85^{\prime} \mathrm{E}\right)$, and recorded constant temperature and salinity of $7^{\circ} \mathrm{C}$ and $34.5 \%$ respectively.

Preparation of sediment substratum. Subtidal sediment $(0$ to $10 \mathrm{~cm}$ ) was collected from the Oslofjord at Solbergstrand and sieved through a $1 \mathrm{~mm}$ mesh. This sediment, devoid of macrofauna, was homogenised by stirring and transferred to the aquaria to obtain a depth of 6 to $7 \mathrm{~cm}$. The sediment had the following concentrations based on dry weight: $0.8 \%$ total organic carbon (TOC), $0.03 \%$ inorganic carbon, and $0.1 \mu \mathrm{g} \mathrm{g}^{-1} \mathrm{Cd}$. Sulfide electrodes (Ag/AgS) were positioned within the sediment of each aquarium to continuously monitor and record sediment sulfide ion production at a depth of 1 to $2 \mathrm{~cm}$ throughout the experimental period. Redox potentials measured at 1 to $2 \mathrm{~cm}$ depth from the sediment surface were determined weekly on a standard Radiometer $\mathrm{P} 101$ platinum electrode against a $\mathrm{Ag} / \mathrm{AgCl}$ reference electrode. The system was allowed to stabilise for $1 \mathrm{wk}$ before the addition of the experimental organisms.

Preparation of experimental organisms. All aquaria contained the same 'experimental population' of macrofauna selected on the basis of their different trophic strategies. Among the individuals added were 2 ophiuroid brittle-star species, Amphiura filiformis (Müller) ( $\mathrm{n}=10$ ) and Amphiura chiajei (Forbes) ( $\mathrm{n}=5$ ), representing a total amphiurid density of 88 ind. $\mathrm{m}^{-2}$ Although this is considerably lower than natural high density areas of up to 3900 ind. $\mathrm{m}^{-2}$, both species are often found in low numbers throughout their range (Munday \& Keegan 1992). These 2 amphiurid species display differences in their feeding strategies, with $A$. filiformis described as a rapidly growing, short-lived suspension feeder with a high metabolic rate, and $A$. chiajei described as a long-lived, slow growing deposit feeder with a correspondingly low metabolic rate.

The bivalve species Abra alba (Wood) ( $n=16$ ) represented a density of 94 ind $\mathrm{m}^{-2}$, comparable to mixed 
benthic communities in the Bay of Morlaix, Brittany, France (Ibanez \& Dauvin 1988). A. alba is a deposit feeding bivalve that burrows 3 to $5 \mathrm{~cm}$ in depth and, from below the surface, sucks up the thin top sediment layer by movement of its long siphons, which are 4 to $5 \mathrm{~cm}$ in length (Amouroux et al. 1989). Sampling of the bivalves and brittle-stars was conducted at the mouth of the Gullmarsfjord, western Sweden $\left(58^{\circ} 14.72^{\prime} \mathrm{N}\right.$, $11^{\circ} 25.80^{\prime} \mathrm{E}$ ), at a depth of $40 \mathrm{~m}$.

The common polychaete Nereis (Hediste) diversicolor (Müller) ( $\mathrm{n}=16$ ) was represented at a density of 94 ind. $\mathrm{m}^{-2} \mathrm{~N}$. diversicolor exhibits diverse feeding strategies and has been described as a carnivore, a scavenger, a suspension feeder and a surface-deposit feeder, feeding partly by ingesting detritus and microphytobenthos around the burrow opening (Riisgård 1994). The growth of $N$. diversicolor was used to monitor the potential food 'quality' of the organic enrichments, and it was selected due to its diverse feeding strategies, infaunal nature and wide geographical distribution. The ease and accuracy of measuring changes in biomass in this species was favoured in contrast to more complex growth and energy partitioning regimes found in bivalves and amphiurids (Sköld et al. 1994), which are often dependent on an array of interacting environmental factors. $N$ diversicolor was collected south of the marine station at Solbergstrand and weighed prior to addition to the microcosm system and at the termination of the experiment. The average biomass per aquarium was used to determine the percentage growth of this polychaete species, thus taking mortality into consideration.

Experimental design. The experiment consisted of 3 sources of organic enrichment: cellulose fibres, sewage and benthic algae Ulva lactuca, dosed with regard to the organic carbon content in 4 pulse additions. Two dosage levels supplied a total enrichment of 2 and $4 \mathrm{~g}$ $\mathrm{C}$ over the $70 \mathrm{~d}$ experimental period, representing monthly organic additions of 5 (low) and $10 \mathrm{~g} \mathrm{C} \mathrm{m}^{-2}$ (high) respectively; these concentrations are comparable to those used by Grassle et al. (1985), where powdered Ascophyllum was added to a mesocosm system to accomplish final levels of $15 \mathrm{~g} \mathrm{C} \mathrm{m}^{-2}$ and resulted in significant faunal community changes. The cellulose fibre effluent originated from a Norwegian thermomechanical pulp production (integrated newsprint) mill, using Norwegian spruce Picea abies and applying a combined ground wood/thermomechanical method and bleaching primarily with hydrosulfite. Primary treated sewage was collected from a sewage plant, Bekkelaget, serving the Oslo catchment area and was removed from the primary sedimentation basin after it had undergone non-chemical treatment by screening and aeration. The cultured benthic algae $U$. lactuca was freeze-dried and ground before its addition to the
Table 1 Description of organic enrichment techniques. Total organic carbon (TOC), and total nitrogen (TOT-N) were determined by a Skaler Autoanalyser and catalytic combustion method (Dohrman DC-190), respectively, for both the fibre and sewage fluid treatments, and with a Carlo Erba Elemental Analyser 1106 for the algae. Cadmium (Cd) was analysed by absorption spectrophotometry (Perkin Elmer 2280)

\begin{tabular}{|lccc|}
\hline & \multicolumn{3}{c|}{ Organic enrichment material } \\
& Fibres & Sewage & Algae \\
\hline TOC $\left(\mathrm{mg} \mathrm{g}^{-1}\right)$ & 944 & 2588 & 298 \\
TOT $-\mathrm{N}\left(\mathrm{mg} \mathrm{g}^{-1}\right)$ & 19 & 570 & 32 \\
Cd $\left(\mathrm{\mu g} \mathrm{g}^{-1}\right)$ & 18.2 & 10.4 & 2.4 \\
\hline
\end{tabular}

microcosm system. A description of the organic enrichment treatments is shown in Table 1.

In the pulse experiments, material was added to the water phase of each aquarium in 4 batches over the experimental period of $10 \mathrm{wk}$. On each occasion the organic treatment was combined with a standard $\mathrm{Cd}$ dose $(250 \mu \mathrm{g})$, prepared from a stock solution of $\mathrm{CdCl}_{2}$, and $200 \mathrm{mg}$ wet sediment which was stirred mechanically for $10 \mathrm{~min}$ before addition. The standard $200 \mathrm{mg}$ fresh sediment provided a control substrate for the $\mathrm{Cd}$ additions in the $\mathrm{Cd}$ control, and was therefore added to all treatments and controls. When the organic batches were added, the flow-through water system was disconnected for $6 \mathrm{~h}$ to ensure maximum sedimentation of the material within the aquaria, and oxygen levels at the sediment surface were monitored subsequent to the addition. The retention of organic material and added $\mathrm{Cd}$ was determined by the collection and analysis of water samples from the aquaria outlet at regular time intervals for analysis. The time-series integrated organic carbon and Cd content from the outflow measurements, minus the control, represented the loss of material over time, and thus retention values could be calculated. The reference aquaria $(-\mathrm{Cd})$ had no $\mathrm{Cd}$ or organic additions, they contained only the $200 \mathrm{mg}$ of sediment, and no additional organic material was added to the $\mathrm{Cd}$ control aquaria $(+\mathrm{Cd}$ ), only $200 \mathrm{mg}$ of sediment and $250 \mu \mathrm{g} \mathrm{Cd}$. Three replicates were implemented for all treatments, as outlined in the experimental design summarised in Table 2.

Metal analysis. $\mathrm{Cd}$ in the sediment and pore water was analysed at the termination of the experiment from sediment core samples. Following the removal of the overlying water, 5 cores of sediment were taken from each aquarium to allow for possible spatial variation, using a modified syringe $(2 \mathrm{~cm}$ diameter). Each core was subsequently sectioned into $1 \mathrm{~cm}$ slices, pooled by depth section and immediately centrifuged at $20200 \times g, 10^{\circ} \mathrm{C}$ for 15 min to extract the pore water from each section. This specification for the centrifugation procedure allowed all particles with a radius 
Table 2. Experimental design

\begin{tabular}{|cccc|}
\hline $\begin{array}{c}\text { Number of } \\
\text { mucrocosms }\end{array}$ & Treatment & $\begin{array}{c}\text { Organic } \\
\text { dose }\end{array}$ & $\begin{array}{c}\text { Cadmium } \\
\text { addition } \\
(1 \mathrm{mg} \text { total })\end{array}$ \\
\hline 3 & Reference & None & $-\mathrm{Cd}$ \\
3 & Cd Control & None & $+\mathrm{Cd}$ \\
3 & Fibres & Low & $+\mathrm{Cd}$ \\
3 & Fibres & High & $+\mathrm{Cd}$ \\
3 & Sewage & Low & $+\mathrm{Cd}$ \\
3 & Sewage & High & $+\mathrm{Cd}$ \\
3 & Algae & Low & $+\mathrm{Cd}$ \\
3 & Algae & High & $+\mathrm{Cd}$ \\
\hline
\end{tabular}

greater than $0.1 \mu \mathrm{m}$ to settle in accordance with Stoke's Law, and these were subsequently classified as particulate sediment, in contrast to the pore water fraction.

The supernatant pore water was decanted for subsequent $\mathrm{Cd}$ analysis. Total labile $\mathrm{Cd}$ was determined by differential pulse anodic stripping voltammetry (DPASV) in the dissolved fraction using an Eco Chemie Autolab Polarographic Analyser equipped with a Metrohm electrode stand (Abdullah et al. 1976), and standards were made up using pure salts of the metal. Water samples were buffered with sodium acetate $(2$ M) to ensure a stable $\mathrm{pH}$ and also to increase the sensitivity. The $\mathrm{Cd}$ within the sediment fraction was digested with aqua regia $\left(\mathrm{HCl}: \mathrm{HNO}_{3}=3: 1\right)$, and determined by electrothermal atomic absorption spectrophotometry (ETAAS) (Perkin-Elmer $1100 \mathrm{~B})$. The detectable lower limit of this procedure was $0.005 \mu \mathrm{g}$ $\mathrm{g}^{-1} \mathrm{Cd}$, with $10 \%$ RSD (relative standard deviation).

Animals were retrieved by gently washing the contents of each aquarium into a sieve, and $\mathrm{Cd}$ analysis was performed on fresh tissue samples of the 4 species. The bivalves (Abra alba) were left for $24 \mathrm{~h}$ in plain sea water to provide sufficient time for their digestive tracts to clear of sediment (Grémare et al. 1991). Samples were freeze-dried, digested in concentrated nitric acid, $\mathrm{HNO}_{3}$ (Aristar), diluted with $0.1 \mathrm{M} \mathrm{HNO}_{3}$ and analysed by atomic absorption spectrophotometry (AAS) (Perkin-Elmer 2280) with deuterium background correction (Marigómez et al. 1990). Standards were made up in $0.1 \mathrm{M} \mathrm{HNO}_{3}$

Statistical analysis. Organic $\mathrm{C}$ and $\mathrm{Cd}$ retention data were analysed using 2-way analysis of variance (ANOVA) to test the significance of treatment effects $(\alpha=0.05)$, with organic types and dose as factors. Analysis of sediment and pore water Cd data involved ANOVA, with organic treatments, dosage levels and depth as factors (no depth factor for the total core analysis). Homogeneity of variances was tested using Cochran's C and Bartlett's $\chi^{2}(\alpha=0.05)$ (Underwood 1981). Data for sediment $\mathrm{Cd}$ were corrected for heteroscedasticity by $\log _{10}$-transformations as recom- mended when mean values are positively correlated with the variance (Sokal \& Rohlf 1981). When first order interactions were significant, post hoc comparisons were performed using Duncan's Multiple Range test. Data for $\mathrm{Cd}$ in animal tissues were analysed as above using 2-way ANOVA after correction for heteroscedasticity by $\log _{10}$-transformation. All bioaccumulation and growth data were additionally analysed by ANCOVA to determine the relative contribution of the 2 factors organic type and dosage level to the observed effects. Changes in the redox and sulfide profiles with time were determined by 2 -way ANOVA, with organic treatment and time as factors. Cd was combined with all organic enrichment treatments in this study and thus all analytical comparisons for the organic treatments were made to the $\mathrm{Cd}$ control.

\section{RESULTS}

\section{Retention of organic material and $\mathrm{Cd}$ in the aquaria}

The retention of both organic material and Cd was calculated by estimating the percentage loss of material from the aquaria after each addition. There were significant differences in the organic carbon content retained by treatments, with more being lost from both fibre treatments compared to the other organic enrichment treatments (Table 3). However, both fibre treatments still represented a significant organic enrichment equivalent to monthly additions of 8.5 and $4.5 \mathrm{~g} \mathrm{C} \mathrm{m}^{-2}$ for the high and low dosage treatments respectively. A significant dosage effect indicated that slightly more organic material was lost at high organic dosage levels, but this additional loss never exceeded $5 \%$. Cd retention also showed variation between treatments, with a Cd retention of $77 \%$ in the Cd control compared to between 86 and $95 \%$ for the organic enrichment treatments. A significant organic dosage response indicated that more $\mathrm{Cd}$ was retained with increased organic material at the high dosage levels (Table 3 ).

\section{Sediment chemistry}

\section{Redox and sulfide activity}

Comparison of reference $(-C d$, -organics) and $C d$ control $(+C d$, -organics). Redox potentials and sulfide ion activity were monitored at 1 to $2 \mathrm{~cm}$ depth from the sediment surface, and the results are illustrated in Fig 1, with arrows indicating the input of organic material batches to the system. There were no significant differences in the redox profiles between the reference $(-\mathrm{Cd})$ and the $\mathrm{Cd}$ control $(+\mathrm{Cd})$, suggesting that 
Table 3. Percentage retention of added organic carbon and cadmium, and the corresponding total amounts retained in the aquaria after the 4 additions. For $\mathrm{Cd}$ data, asterisks $\left({ }^{*}\right)$ indicate significant differences from the $\mathrm{Cd}$ control $(+\mathrm{Cd})$ when $\alpha<0.05$

\begin{tabular}{|c|c|c|c|c|c|c|}
\hline \multirow[t]{2}{*}{ Treatment } & \multirow[t]{2}{*}{ Organic dose } & & \multicolumn{2}{|c|}{ Organic carbon } & \multicolumn{2}{|c|}{ Cadmium } \\
\hline & & & Retention $(\%)$ & Total retained $(\mathrm{g})$ & Retention (\%) & Total retained $(\mu \mathrm{g})$ \\
\hline Cd control & None & $+\mathrm{Cd}$ & No additions & No additions & 77 & 771 \\
\hline Fibres & $\begin{array}{l}\text { Low } \\
\text { High }\end{array}$ & $\begin{array}{l}+\mathrm{Cd} \\
+\mathrm{Cd}\end{array}$ & $\begin{array}{l}91 \\
86\end{array}$ & $\begin{array}{l}1.81 \\
3.42\end{array}$ & $\begin{array}{l}92^{\circ} \\
93^{\circ}\end{array}$ & $\begin{array}{l}923^{\circ} \\
929^{\circ}\end{array}$ \\
\hline Sewage & $\begin{array}{l}\text { Low } \\
\text { High }\end{array}$ & $\begin{array}{l}+\mathrm{Cd} \\
+\mathrm{Cd}\end{array}$ & $\begin{array}{l}95 \\
93\end{array}$ & $\begin{array}{l}1.90 \\
3.72\end{array}$ & $\begin{array}{l}93^{\circ} \\
95^{\circ}\end{array}$ & $\begin{array}{l}925^{\circ} \\
947^{\circ}\end{array}$ \\
\hline Algae & $\begin{array}{l}\text { Low } \\
\text { High }\end{array}$ & $\begin{array}{l}+\mathrm{Cd} \\
+\mathrm{Cd}\end{array}$ & $\begin{array}{l}95 \\
94\end{array}$ & $\begin{array}{l}1.91 \\
3.77\end{array}$ & $\begin{array}{l}86^{\circ} \\
95^{\circ}\end{array}$ & $\begin{array}{l}858^{\circ} \\
945^{\circ}\end{array}$ \\
\hline
\end{tabular}

the addition of $\mathrm{Cd}$ had no significant effect on the redox potential in this experiment (Table 4). The redox profile followed peaks and troughs over the experimental period, reaching a maximum of 517 Eh during the first $2 \mathrm{wk}$ of the experiment. The addition of fresh sediment (200 $\mathrm{mg}$ ) appeared to have stimulated the system, thereby possibly increasing bioturbatory activity and the diffusion of oxygen. Such peaks are especially clear in the sulfide results corresponding to the final 2 additions in Weeks 6 and 8. The sulfide profiles, however, do indicate a significant increase in sulfide activity, represented by a decrease in $\mathrm{mV}$ values in the $\mathrm{Cd}$ control, from a mean value of -19 in the reference to -177 in the Cd control ( $p<0.001)$.

Comparison of $\mathrm{Cd}$ control $(+\mathrm{Cd}$, -organics) and organic treatments ( $+C d$, +organics). Sediment redox activities for the fibre treatments were not significantly different to the Cd control as seen in Fig. 1, although lower sulfide levels were recorded for the low dosage treatment over the second half of the experiment. The sewage-treated sediment showed considerable variation. The redox activity of both sewage doses were similar until Week 5, after which the peaks and troughs of the low dosage sewage treatment were much more pronounced compared to the $\mathrm{Cd}$ control, possibly indi- cating intense biological activity in response to the additional food supply. In comparison, after Week 5 the high dosage sewage treatment showed a steady reduction in the redox levels to minimum values of $107 \mathrm{Eh}$, with significant variation in the profile compared to the Cd control $(p<0.05)$. Although the sulfide profile for the sewage treatment maintained the narrow peaks in response to the organic additions, low dosage treatments stimulated the system by a decrease in sulfide activity indicated by significant increases in $\mathrm{mV}$ values compared to the $\mathrm{Cd}$ control $(\mathrm{p}<0.05)$, whilst high dosage levels showed a steady increase in sulfide activity after Week 2 ( $p<0.05$ ) (Table 4 ).

In comparison, the algal treatment showed sediment changes in redox potentials commencing from Week 4 , with the low and high dosage levels diverging. The redox profile for the low dosage algae treatment followed a trend similar to that of the Cd control, maintaining the pronounced peaks and troughs, but at significantly lower Eh $(p<0.05)$. Compare this to the high algal treatment, which continuously decreased after the second enrichment, reaching a minimum at Week 10 of 62 Eh $(p<0.001)$. Sulfide results for both the low and high dosage of algae indicated relatively high sulfide activity compared to the Cd control $(\mathrm{p}<0.01$ ) (Table 4 ).

Table 4. Results of mean redox potentrals and sulfide activity over the experimental period for all treatments. p-values represent the significance probabilities from 2-way ANOVA (Treatment $\times$ Time) and asterisks (") denote statistical differences from the Cd control $(+\mathrm{Cd})$

\begin{tabular}{|c|c|c|c|c|c|c|}
\hline Treatment & Organic dose & & $\begin{array}{l}\text { Mean redox } \\
\text { potential (Eh) }\end{array}$ & $\mathrm{p}$ & $\begin{array}{l}\text { Mean sulfide } \\
\text { activity (mV) }\end{array}$ & $\mathrm{p}$ \\
\hline Cd control & None & $+\mathrm{Cd}$ & 302 & - & -177 & - \\
\hline Reference & None & $-\mathrm{Cd}$ & 320 & 0.30 & -19 & $0.00^{\circ}$ \\
\hline Fibres & $\begin{array}{l}\text { Low } \\
\text { High }\end{array}$ & $\begin{array}{l}+\mathrm{Cd} \\
+\mathrm{Cd}\end{array}$ & $\begin{array}{l}291 \\
297\end{array}$ & $\begin{array}{l}0.77 \\
0.19\end{array}$ & $\begin{array}{l}-104 \\
-171\end{array}$ & $\begin{array}{l}0.00^{\circ} \\
0.45\end{array}$ \\
\hline Sewage & $\begin{array}{l}\text { Low } \\
\text { High }\end{array}$ & $\begin{array}{l}+\mathrm{Cd} \\
+\mathrm{Cd}\end{array}$ & $\begin{array}{l}326 \\
253\end{array}$ & $\begin{array}{l}0.43 \\
0.02\end{array}$ & $\begin{array}{l}-145 \\
-196\end{array}$ & $0.00^{\circ}$ \\
\hline Algae & $\begin{array}{l}\text { Low } \\
\text { High }\end{array}$ & $\begin{array}{l}+\mathrm{Cd} \\
+\mathrm{Cd}\end{array}$ & $\begin{array}{l}287 \\
196\end{array}$ & $\begin{array}{l}0.04^{\circ} \\
0.00^{\circ}\end{array}$ & $\begin{array}{l}-210 \\
-208\end{array}$ & $\begin{array}{l}0.00^{\circ} \\
0.00^{\circ}\end{array}$ \\
\hline
\end{tabular}


A
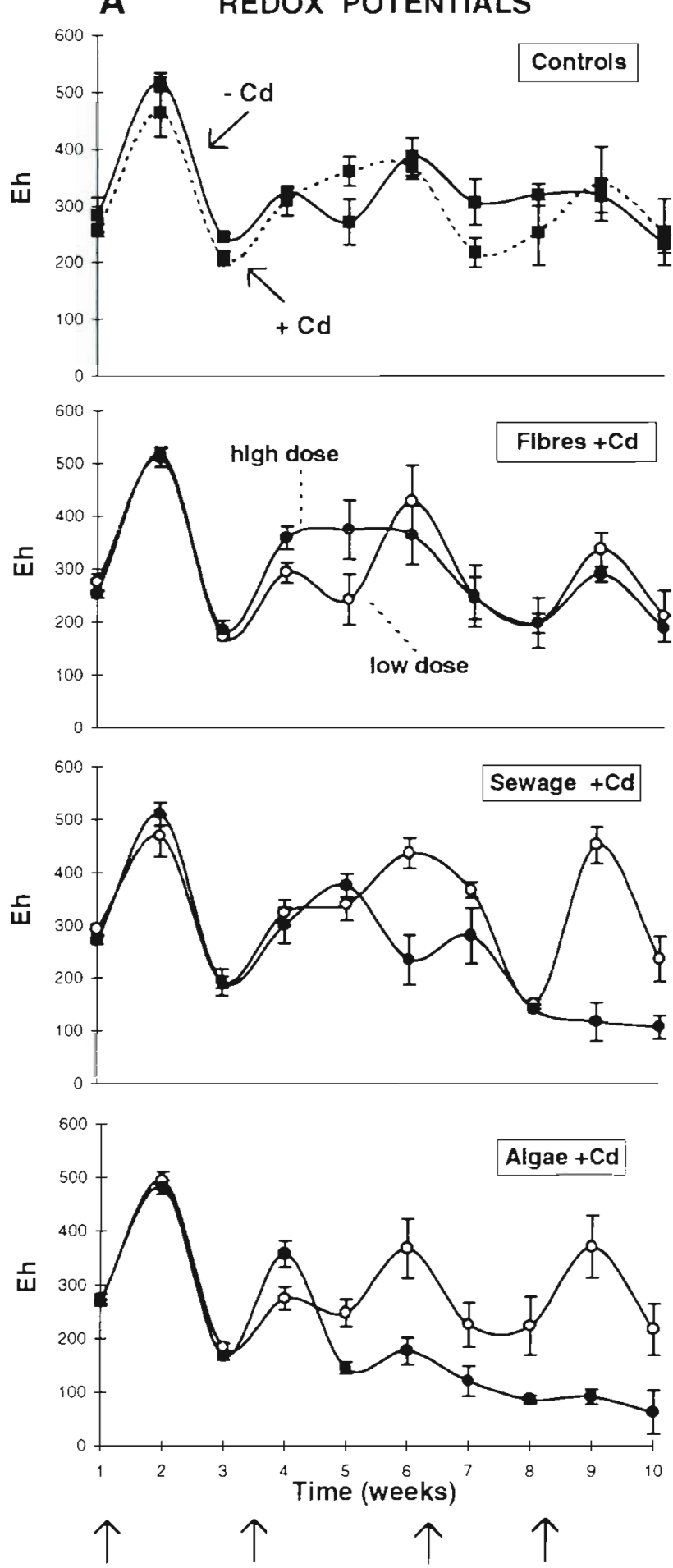
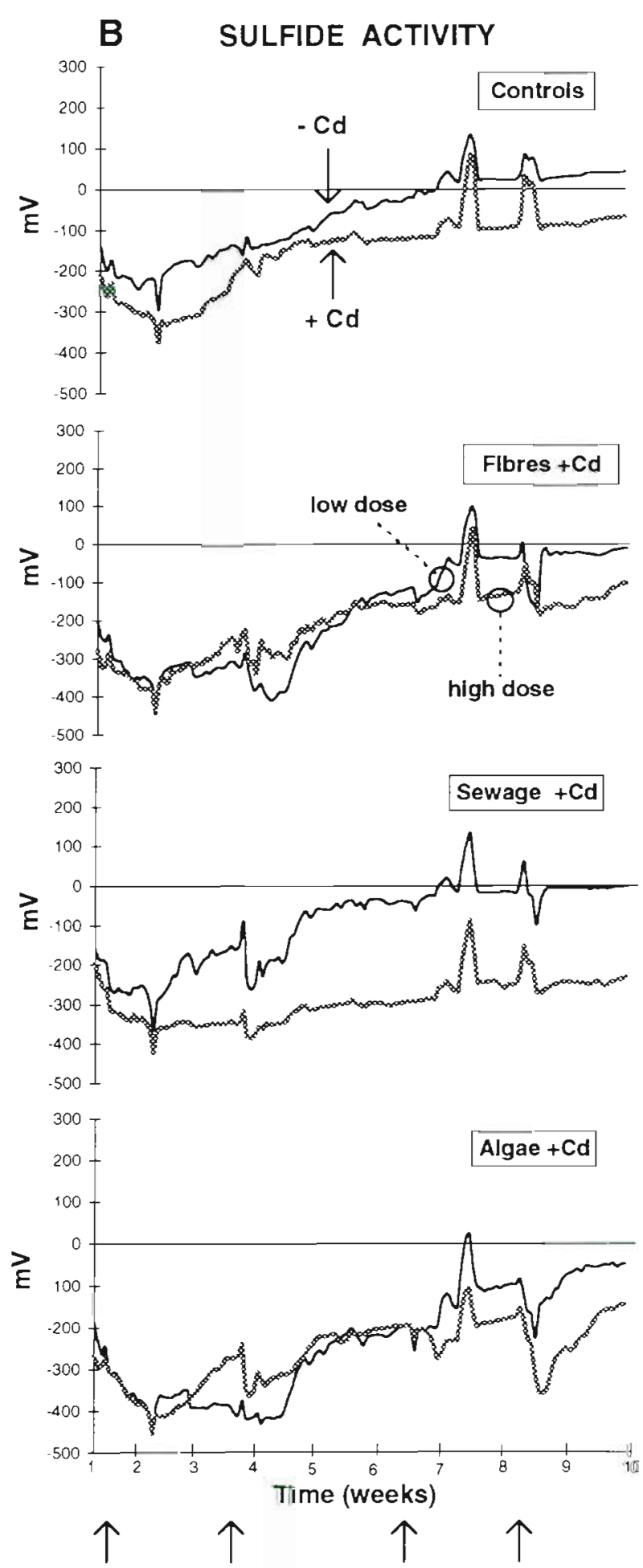

Fig. 1. Redox and sulfide changes over the experimental period; arrows indicate addition of organic material. (A) Sediment redox potential for the controls ( $\mathbf{a}$ ) and 3 organic enrichment treatments, fibres, sewage and algae, at low dose (0) and high dose ( $)$ Error bars denote \pm SE. (B) Sediment sulfide actuvity recorded every $12 \mathrm{~h}$ for the controls and organic enrichment treatments at a low dose (solid line) and high dose (shaded line) 


\section{Transport and partitioning of $\mathrm{Cd}$}

Cd in the sediment substratum

Total sediment core analysis. Results for sediment Cd concentrations, or $[\mathrm{Cd}]_{\text {sed }}$, in the total core indicated increases in $[\mathrm{Cd}]_{\text {sed }}$ in the $\mathrm{Cd}$ control $(+\mathrm{Cd})$ compared to the reference, and these differences were marginally significant $(0.05<\mathrm{p}<0.1)$ (Fig. 2A). Two-way ANOVA, with organic type and dosage level as factors, showed a statistically significant organic effect $(p<0.001)$, indicating that the addition of organic material affected the $[\mathrm{Cd}]_{\text {sed }}$; however, there was no apparent effect of the organic dosage when considering the total core $[\mathrm{Cd}]_{\text {sed }}$. This significant organic effect was due to the low $[\mathrm{Cd}]_{\text {sed }}$ values in the fibre-enriched treatment, with both dosage levels of fibre resulting in less than $0.1 \mu \mathrm{g}$ $\mathrm{g}^{-1} \mathrm{Cd}$ DW (dry weight) in the sediment, comparable to reference concentrations with no additional $\mathrm{Cd}$. The sewage and algal treatments resulted in slightly higher $[\mathrm{Cd}]_{\text {sed }}$ in the total core than the Cd control, but these were not significantly different (Fig. 2A).
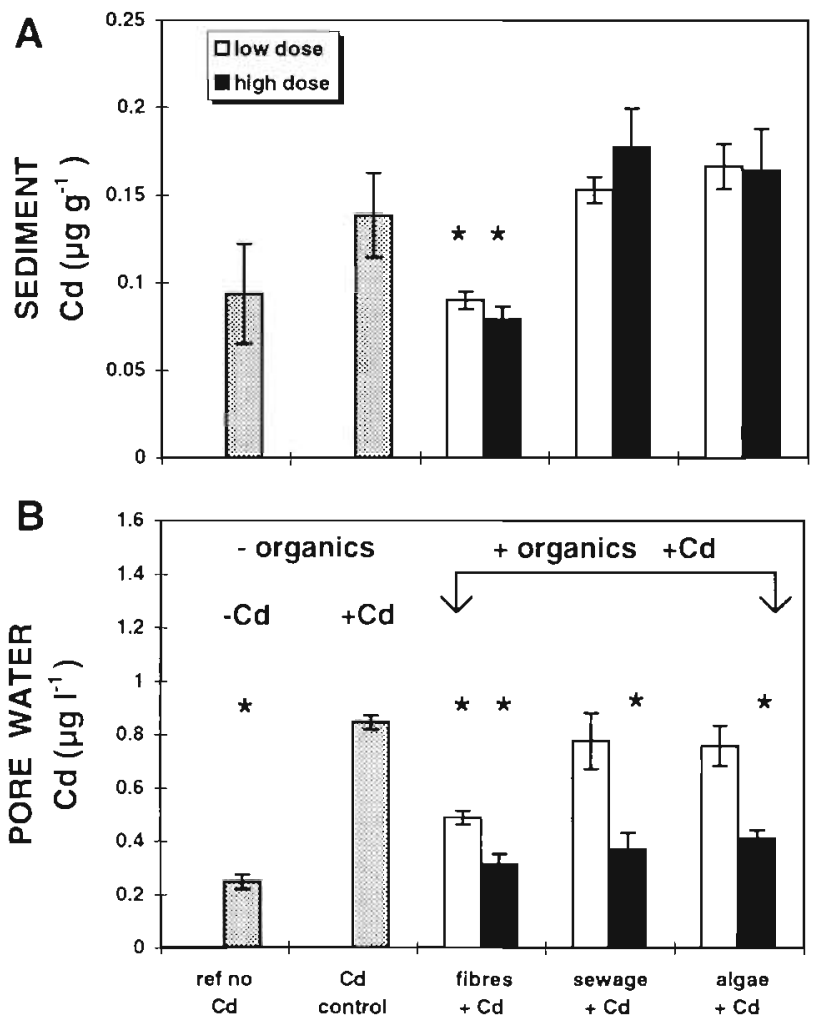

Fig. 2. Total sediment core cadmium concentrations for the (A) sediment and (B) pore water phases of a microcosm system subjected to 3 different organic enrichment treatments combined with constant $\mathrm{Cd}$ additions, and controls: reference $(-\mathrm{Cd})$ and $\mathrm{Cd}$ control $(+\mathrm{Cd})$. 'Concentrations significantly different from the $\mathrm{Cd}$ control $(+\mathrm{Cd})$ when $\alpha<0.05$. Error bars denote $\pm \mathrm{SE}$
Depth analysis. Analysis of $[\mathrm{Cd}]_{\text {sed }}$ with depth revealed changes in $\mathrm{Cd}$ concentration through the sediment core not obvious from the total core results; these changes are illustrated in Fig. 3A. A comparison by ANOVA of $[\mathrm{Cd}]_{\text {sed }}$ depth profiles in the reference and $\mathrm{Cd}$ control revealed a significant effect of the $\mathrm{Cd}$ additions $(p<0.01)$ and a positive 2 -way interaction between the addition of $\mathrm{Cd}$ and depth $(\mathrm{p}<0.01)$, which confirmed that the addition of $\mathrm{Cd}$ in the $\mathrm{Cd}$ control affected the $[\mathrm{Cd}]_{\text {sed }}$ depth profile compared to the reference. This is clear by the magnitude of the difference in $\mathrm{Cd}$ in the top $2 \mathrm{~cm}$ of the sediment between the 2 groups as seen in Fig. $3 \mathrm{~A}$, which shows that $[\mathrm{Cd}]_{\text {sed }}$ concentrations in the $\mathrm{Cd}$ control $(+\mathrm{Cd})$ doubled in the surface $2 \mathrm{~cm}$ from $0.1 \mu \mathrm{g} \mathrm{g}^{-1}$ in the reference $(-\mathrm{Cd})$ to $0.2 \mu g g^{-1}$.

Results from 3-way ANOVA of $[\mathrm{Cd}]_{\text {sed }}$ with organic type, dosage level and depth as factors revealed that the type of organic material strongly influenced the 'shape' of the $[\mathrm{Cd}]_{\text {sed }}$ depth profile, as seen from a positive 2 -way interaction effect $(p<0.001)$. The dosage level of the fibre and algae organic treatments had no

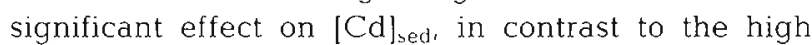
dosage sewage treatment, which resulted in a clear increase in $[\mathrm{Cd}]_{\text {sed }}$ in the upper $2 \mathrm{~cm}$ of sediment compared to the low dosage level. The addition of fibres resulted in significantly lower $[\mathrm{Cd}]_{\text {sed }}$ in the upper $3 \mathrm{~cm}$ than in the $\mathrm{Cd}$ control, whereas in the sewage and algae enrichments changes in $[\mathrm{Cd}]_{\text {sed }}$ occurred primarily in the upper $2 \mathrm{~cm}$, with significantly higher $C d$ in the surface to $1 \mathrm{~cm}$ region and slightly less in the 1 to $2 \mathrm{~cm}$ band compared to the Cd control (Fig. 3A, Table 5).

$\mathrm{Cd}$ in the pore water

Total core analysis. Results for Cd pore water concentrations, or $[\mathrm{Cd}]_{p w}$, in the total core, in accordance with $[\mathrm{Cd}]_{\text {sed }}$ core results, showed a highly significant increase $(p<0.001)$ from the reference to the $C d$ control (Fig 2B). The magnitude of this difference was greater in the pore water, being more than a 3 -fold increase (from $0.25 \mathrm{\mu g} \mathrm{l}^{-1}$ to $0.85 \mathrm{\mu g} \mathrm{l}^{-1}$ ) compared to increases in $[\mathrm{Cd}]_{\text {sed }}$. Interestingly, with the addition of all types of organic material, $[\mathrm{Cd}]_{\mathrm{pw}}$ decreased $(\mathrm{p}<$ 0.05 ), with a highly significant dosage effect ( $\mathrm{p}<$ $0.001)$. This significant dosage effect reflected that an increase in the organic enrichment from $2 \mathrm{~g} \mathrm{C}$ to $4 \mathrm{~g} \mathrm{C}$ resulted in a considerable reduction in $[\mathrm{Cd}]_{\mathrm{pw}}$ of at least one third for all of the organic treatments.

Depth analysis. A comparison of depth analysis results for $[\mathrm{Cd}]_{\mathrm{pw}}$ between the reference $(-\mathrm{Cd})$ and $\mathrm{Cd}$ control $(+\mathrm{Cd})$ indicated a significant increase in $\mathrm{Cd}$ in the top $3 \mathrm{~cm}$ of sediment in the $\mathrm{Cd}$ control, confirming 
A SEDIMENT Cd $\left(\mu \mathrm{g} \mathrm{g}^{-1}\right)$

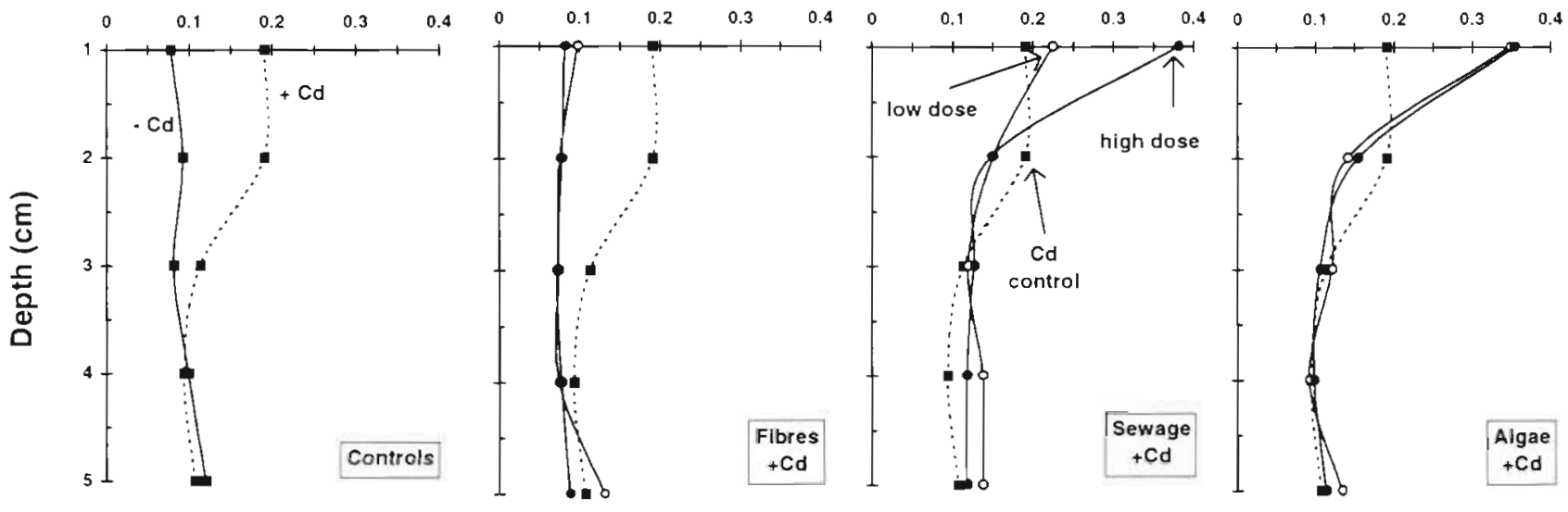

B PORE WATER Cd $\left(\mu \mathrm{g} \mathrm{l}^{-1}\right)$
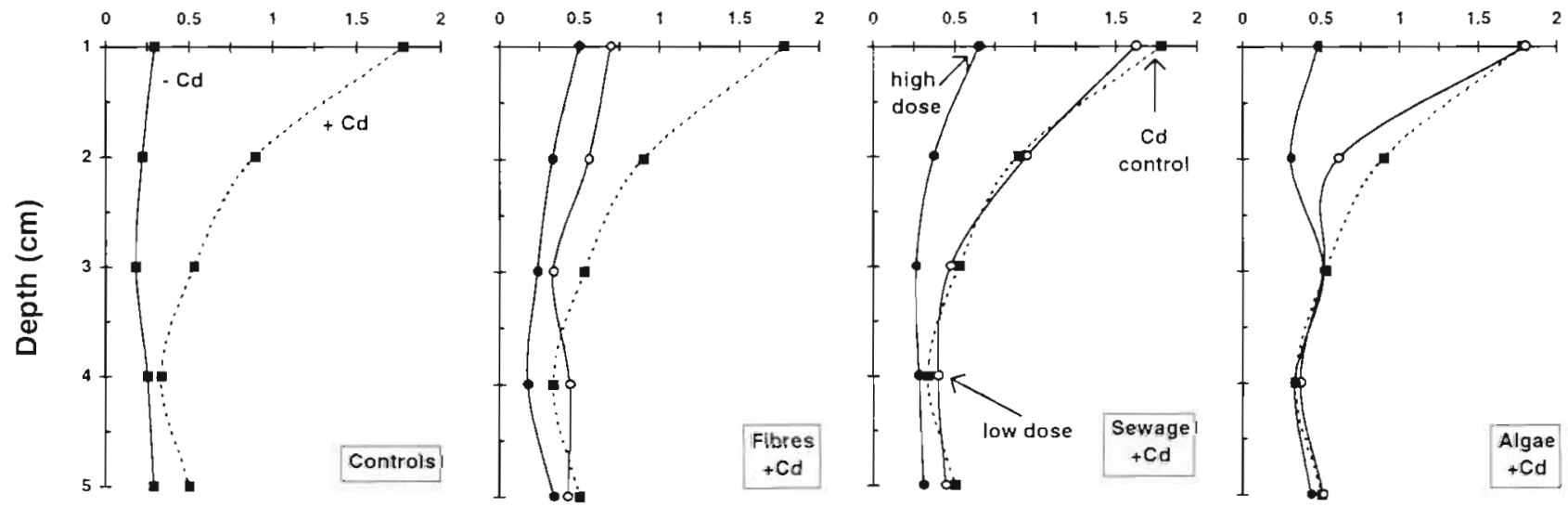

Fig. 3. Depth profiles of (A) sediment and (B) pore water cadmium concentrations for the controls ( $\mathbf{\square}$ ) and 3 organic enrichment treatments, fibres, sewage and algae, at low dose $(0)$ and high dose $(\bullet)$ with constant cadmium additions

strongly, as with $[\mathrm{Cd}]_{\text {sed }}$ results, that the addition of $\mathrm{Cd}$ in the $\mathrm{Cd}$ control affected the depth profile of $[\mathrm{Cd}]_{\mathrm{pw}}$ (Fig. 3B). This represented a 6 -fold increase in [Cd $]_{p w}$ in the top $1 \mathrm{~cm}$, a 3 -fold increase in the 1 to $2 \mathrm{~cm}$ region, and a doubling in the 2 to $3 \mathrm{~cm}$ region.

Results from 3-way ANOVA with organic type, dosage level and depth as factors revealed that $[\mathrm{Cd}]_{\text {pw }}$ at different depth levels was significantly different, with a decrease in $[\mathrm{Cd}]_{\rho \mathrm{w}}$ in the surface to $2 \mathrm{~cm}$ depth level for all organic treatments compared to the $\mathrm{Cd}$ control. A highly significant 2-way interaction between dose and depth also indicated that the effect of depth on $[\mathrm{Cd}]_{p w}$ depended on dose for both the algae and sewage treatments $(p<0.001)$. A positive 3 -way interaction effect $(p<0.01)$ confirmed that $[C d]_{p w}$ at different depths was influenced not only by the type of organic material, but also by the dosage (Fig. 3B, Table 6).

\section{Cd bioaccumulation}

A comparison of $\mathrm{Cd}$ bioaccumulation, or $[\mathrm{Cd}]_{\text {bo }}$, between the reference and $\mathrm{Cd}$ control in the brittlestar Amphiura filiformis revealed clear increases $(p<$ 0.01 ) with the addition of $\mathrm{Cd}$. Mean concentrations in the reference and $C d$ control were 0.18 and $0.72 \mu \mathrm{g} \mathrm{g}^{-1}$ respectively. The type of organic material affected $[C d]_{\text {bio }}(p<0.001)$, with significantly less $C d$ in fibre treated $A$. filiformis and more in those treated with algae compared with the Cd controls (Fig. 4). Individuals in high organic treatments contained less $\mathrm{Cd}$ compared to the low dosage level, this effect was marginally significant $(\mathrm{p}=0.089)$ by ANCOVA.

A similar pattern of $[C d]_{\text {bio }}$ was shown for Amphiura chiajei: a significant increase from a mean $\mathrm{Cd}$ tissue concentration of $0.13 \mu \mathrm{g} \mathrm{g}^{-1}$ for the reference to $0.38 \mu \mathrm{g}$ $\mathrm{g}^{-1}$ for the Cd control $(\mathrm{p}<0.05)$. As in A. filiformis, the 
Table 5. Results of 3-way ANOVA for sediment Cd depth profiles. Signifıcance levels reflect significant differences from the Cd control: $\cdots p<0.001$. Orgs: effect of organic treatments; Dose: effect of organic dose; Depth: depth effect

\begin{tabular}{|c|c|c|c|c|}
\hline Source & $\mathrm{df}$ & $\mathrm{MS}$ & F & $\mathrm{p}$ \\
\hline Orgs & 2 & 0.64 & 52.35 & $0.000 \cdots$ \\
\hline Dose & 1 & 0.01 & 0.60 & 0.441 \\
\hline Depth & 4 & 0.33 & 26.66 & $0.000^{\cdots} \cdot$ \\
\hline Orgs $\times$ Dose & 2 & 0.01 & 0.58 & 0.565 \\
\hline Orgs $\times$ Depth & 8 & 0.08 & 6.57 & $0.000 \cdots$ \\
\hline Dose $\times$ Depth & 4 & 0.01 & 1.13 & 0.352 \\
\hline Orgs $\times$ Dose $\times$ Depth & 8 & 0.01 & 0.74 & 0.654 \\
\hline
\end{tabular}

Table 6. Results of 3-way ANOVA for pore water Cd depth profiles. Significance levels reflect significant differences from the $\mathrm{Cd}$ control: ${ }^{\mathrm{ms}} 0.1>\mathrm{p}>0.05$ (marginally significant). $\cdots p<0.01, \cdots p<0.001$. Factors as in Table 5

\begin{tabular}{|lcrcc|}
\hline Source & df & MS & $F$ & $p$ \\
\hline Orgs & 2 & 0.32 & 8.13 & $0.007 \cdots$ \\
Dose & 1 & 2.15 & 55.56 & $0.000 \cdots$ \\
Depth & 4 & 1.15 & 29.65 & $0.000 \cdots$ \\
Orgs $\times$ Dose & 2 & 0.11 & 2.80 & $0.069^{\mathrm{ms}}$ \\
Orgs $\times$ Depth & 8 & 0.12 & 2.96 & $0.007 \cdots$ \\
Dose $\times$ Depth & 4 & 0.44 & 11.34 & $0.000 \cdots$ \\
Orgs $\times$ Dose $\times$ Depth & 8 & 0.12 & 3.12 & $0.005 \cdots$ \\
\hline
\end{tabular}

type of organic material affected $[\mathrm{Cd}]_{\text {bio }}$ in $\mathrm{A}$. chiajei ( $p<0.001)$, with a similar decrease in tissue Cd concentrations in fibre treated individuals and an increase in those treated with algae. A. chiajei showed a dosage effect for all organic treatments by ANOVA ( $p<0.05$ ), with a reduction in $[\mathrm{Cd}]_{b,}$ as organic enrichment increased, a pattern similar to that seen for pore water Cd concentrations. Results from ANCOVA showed a marginally significant main effect of dose on $[\mathrm{Cd}]_{\text {bıo }}$ $(p=0.063)$, after the effect of organic type had been removed.

The bivalve Abra alba also showed an increase in $[\mathrm{Cd}]_{\text {bio }}$ from the reference to the Cd control; the magnitude of this increase was much greater than it was for the amphiurids, from $1.71 \mathrm{\mu g} \mathrm{g}^{-1}$ for the reference to $16.21 \mathrm{\mu g} \mathrm{g}^{-1}$ for the Cd control $(\mathrm{p}<0.05)$. Organic enrichment decreased $[\mathrm{Cd}]_{\text {bio }}$ in $A$. alba, with individuals in all organic treatments having reduced $\mathrm{Cd}$ concentrations in their tissues. However, this organic effect was only statistically significant in fibre-treated A. alba, which showed Cd concentrations as low as $0.96 \mu \mathrm{g} \mathrm{g}^{-1}$, levels lower than were found in the reference. An increasing gradient of $\mathrm{Cd}$ bioaccumulation in response to organic enrichment occurred in $A$. alba, as
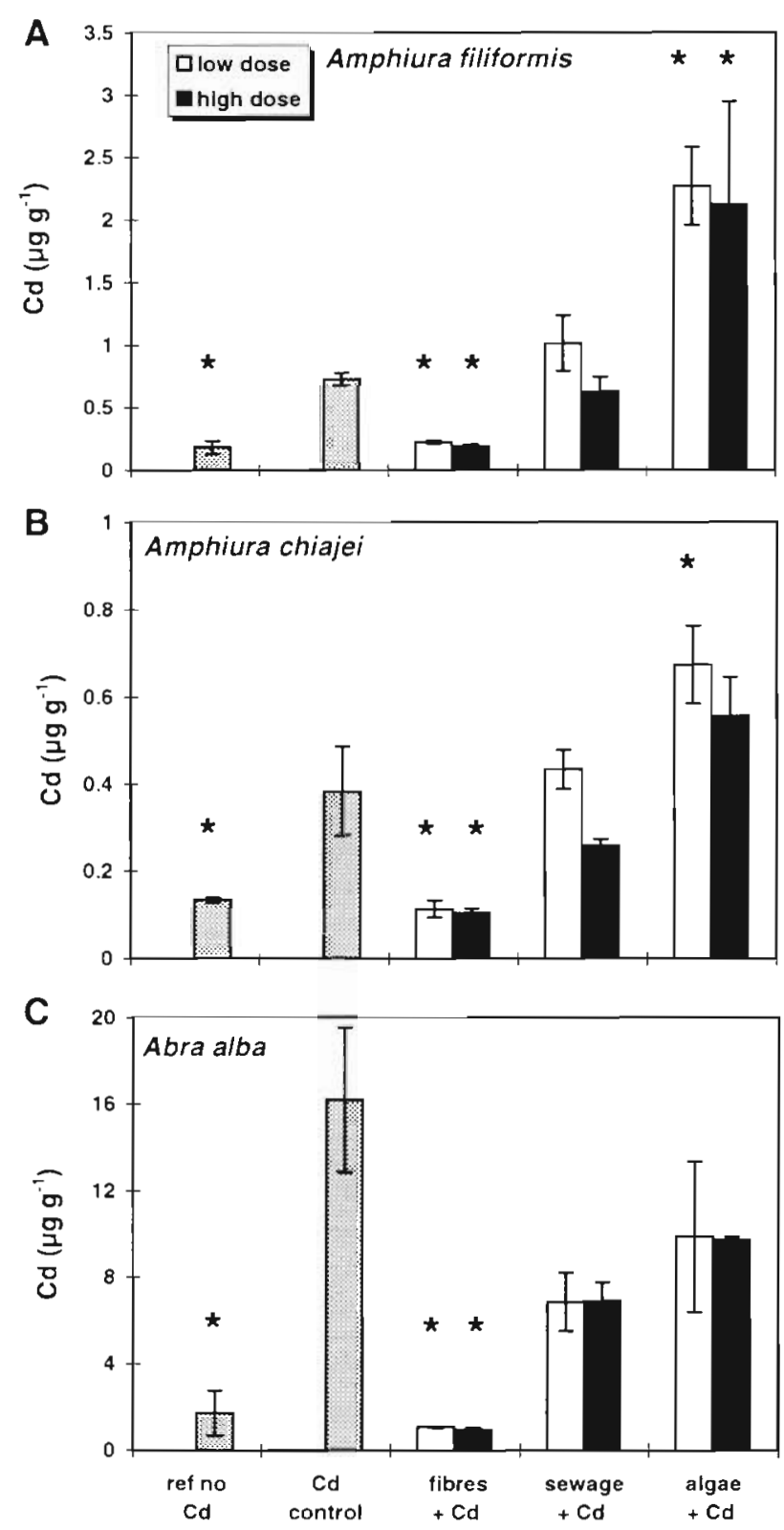

Fig. 4. Cadmium concentrations ( $\mu \mathrm{g} \mathrm{g}^{-1}$ dry wt) in the 3 benthic species, Amphiura filiformis (A). Amphura chiajei (B). and Abra alba $(C)$, after organic enrichment treatments of fibres, sewage and algae, with constant cadmium additions - Concentrations significantly different from the Cd control $(+\mathrm{Cd})$ when $\alpha<0.05$. Error bars denote $\pm \mathrm{SE}$

for the 2 amphiurids, in the sequence: fibres < sewage $<$ algae. No dosage response of organic enrichment on $[\mathrm{Cd}]_{b i 0}$ for $A$. alba was observed by ANOVA or ANCOVA (Table 7).

Table 8 represents a summary of the significance probability values for Cd partitioning between the sediment, pore water and biota compartments in all organic enrichment treatments and the reference 
Table 7 Results of 2-way ANOVAs for Cd bioaccumulation with organic type and dose as factors. Significance levels reflect significant differences from the Cd control: $p<0.05$, $\cdots p<0.001$. Factors as in Table 5

\begin{tabular}{|c|c|c|c|c|}
\hline & $\mathrm{df}$ & $\mathrm{MS}$ & $F$ & $\mathrm{p}$ \\
\hline \multicolumn{5}{|c|}{ Amphiura filiformis } \\
\hline Orgs & 2 & 15.15 & 30.76 & $0.000^{\cdots}$ \\
\hline Dose & 1 & 0.58 & 1.18 & 0.297 \\
\hline Orgs $\times$ Dose & 2 & 0.11 & 0.22 & 0.804 \\
\hline \multicolumn{5}{|c|}{ Amphiura chiajei } \\
\hline Orgs & 2 & 0.87 & 95.66 & $0.000 \cdots$ \\
\hline Dose & 1 & 0.05 & 5.86 & $0.032^{\circ}$ \\
\hline Orgs $\times$ Dose & 2 & 0.02 & 1.74 & 0.216 \\
\hline \multicolumn{5}{|l|}{ Abra alba } \\
\hline Orgs & 2 & 1.56 & 53.25 & $0.000 \cdots$ \\
\hline Dose & 1 & 0.00 & 0.01 & 0.911 \\
\hline Orgs $\times$ Dose & 2 & 0.01 & 0.25 & 0.783 \\
\hline
\end{tabular}

$(-\mathrm{Cd})$, where significant differences from the $\mathrm{Cd}$ control $(+\mathrm{Cd})$ are identified.

\section{Biological effects}

Results of Nereis diversicolor growth rates under different conditions of organic enrichment, but constant $\mathrm{Cd}$ additions, indicated a loss in biomass of up to $20 \%$ of the original individual weight in reference individuals with no organic additions and no $\mathrm{Cd}$, thus suggesting that the microcosm system was in fact food limited for this species. No significant differences were observed between the reference and $\mathrm{Cd}$ control treatments, indicating that $\mathrm{Cd}$ concentrations did not affect the biological processes related to growth. However, the different organic types presented a significant difference in potential food quality, with a distinct doseresponse for growth effects in the different organic treatments (Fig. 5). The effect of organic types on $N$.

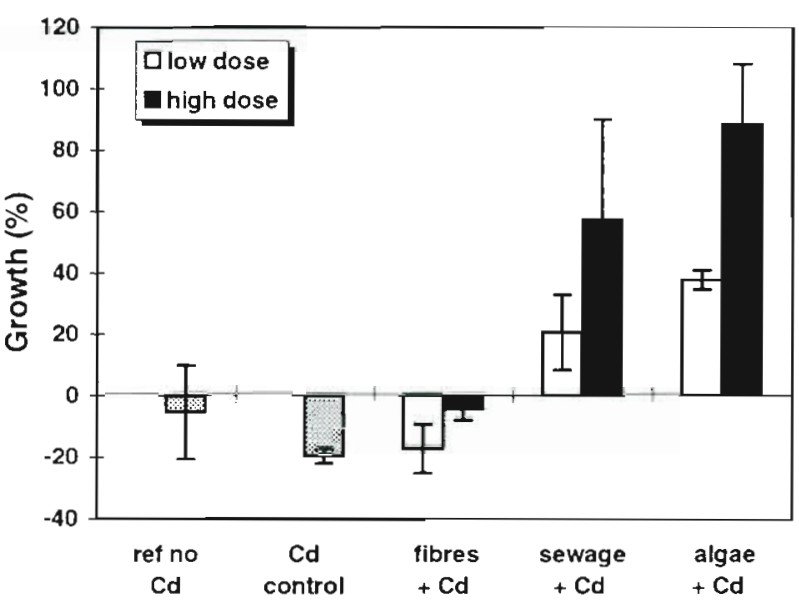

Fig. 5. Nereis diversicolor. Growth expressed as a percentage from the initial biomass. Error bars denote $\pm \mathrm{SE}$

diversicolor growth was highly significant $(p<0.001)$, with increases in growth in sewage and algal treatments as compared to the $\mathrm{Cd}$ control. A significant dosage effect $(p<0.01)$ indicated that increased growth of $N$. diversicolor occurred in all high dosage organic treatments compared to low dose levels and was statistically significant in the sewage and algal treatments. Results of ANCOVA confirmed a highly significant dose effect of organic material on $N$. diversicolor growth after the effects of organic type had been removed.

\section{DISCUSSION}

This study examined the influence of different sources of organic material on the partitioning and bioavailability of $\mathrm{Cd}$ within a model microcosm system. The establishment of the interactions between organic enrichment and the fate of $\mathrm{Cd}$ is especiaily important

Table 8. Duncan's Multiple Range test results indicating post hoc probability (p) values for Cd partitioning between the sediment, pore water and biota compartments for all treatments. Significance levels reflect significant differences from the Cd control (not shown): ${ }^{\text {mns } 0.1}>p>0.05$ (marginally significant), $p<0.05, \cdots p<0.01, \cdots p<0.001$

\begin{tabular}{|c|c|c|c|c|c|c|c|}
\hline Treatment & Organic dose & & $\begin{array}{l}\text { Sediment } \\
\text { (core) }\end{array}$ & $\begin{array}{c}\text { Pore water } \\
\text { (core) }\end{array}$ & $\begin{array}{l}\text { Amphiura } \\
\text { filiformis }\end{array}$ & $\begin{array}{c}\text { Biota } \\
\text { Amphiura } \\
\text { chiajei }\end{array}$ & $\begin{array}{l}\text { Alba } \\
\text { alba }\end{array}$ \\
\hline Reference & None & $-\mathrm{Cd}$ & $0.054^{\mathrm{ms}}$ & $0.000 \cdots$ & $0.026^{\circ}$ & $0.000 \cdots$ & $0.000 \cdots$ \\
\hline $\begin{array}{l}\text { Fibres } \\
\text { Fibres }\end{array}$ & $\begin{array}{l}\text { Low } \\
\text { High }\end{array}$ & $\begin{array}{l}+\mathrm{Cd} \\
+\mathrm{Cd}\end{array}$ & $\begin{array}{l}0.049^{\circ} \\
0.021^{\circ}\end{array}$ & $\begin{array}{l}0.000 \cdots \\
0.000 \cdots\end{array}$ & $\begin{array}{l}0.041^{\circ} \\
0.028^{\circ}\end{array}$ & $\begin{array}{l}0.000 \cdots \\
0.000 \cdots\end{array}$ & $0.000 \cdots$ \\
\hline $\begin{array}{l}\text { Sewage } \\
\text { Sewage }\end{array}$ & $\begin{array}{l}\text { Low } \\
\text { High }\end{array}$ & $\begin{array}{l}+\mathrm{Cd} \\
+\mathrm{Cd}\end{array}$ & $\begin{array}{l}0.519 \\
0.125\end{array}$ & $\begin{array}{l}0.390 \\
0.000 \cdots\end{array}$ & $\begin{array}{l}0.381 \\
0.702\end{array}$ & $\begin{array}{l}0.390 \\
0.117\end{array}$ & $\begin{array}{l}0.094^{\mathrm{ms}} \\
0.102\end{array}$ \\
\hline $\begin{array}{l}\text { Algae } \\
\text { Algae }\end{array}$ & $\begin{array}{l}\text { Low } \\
\text { High }\end{array}$ & $\begin{array}{l}+\mathrm{Cd} \\
+\mathrm{Cd}\end{array}$ & $\begin{array}{l}0.258 \\
0.282\end{array}$ & $\begin{array}{l}0.279 \\
0.000 \ldots\end{array}$ & $\begin{array}{l}0.002 \\
0.004\end{array}$ & $\begin{array}{l}0.012^{\circ} \\
0.068^{\mathrm{ms}}\end{array}$ & $\begin{array}{l}0.186 \\
0.305\end{array}$ \\
\hline
\end{tabular}


due to the high concentration of this metal in organic wastes and the potential danger involved in the conversion of $\mathrm{Cd}$ from an inorganic form into a poisonous metallo-organic compound (Förstner 1980). The subsequent bioaccumulation of $\mathrm{Cd}$ to benthic macrofauna is dependent on the metal partitioning within the sediment/pore water matrix and formed the focus of this study.

\section{Sediment/pore water matrix}

The total exposure of $1 \mathrm{mg} \mathrm{Cd}$ per microcosm, each of which contained approximately $20 \mathrm{l}$ sea water and 9 l sediment, resulted in environmentally realistic $\mathrm{Cd}$ levels in both the sediment matrix and biota, which may be representative of low to moderate contamination to marine areas (Phillips 1977, Roberts et al. 1986). Results indicated significant increases in the $\mathrm{Cd}$ concentrations to both the sediment and pore water compartments in the absence of organic enrichment. The magnitude of this Cd increase was, however, greater in the pore water, representing a 3 -fold percentage increase compared to reference sediments with no additional $\mathrm{Cd}$. An examination of the depth profiles for the Cd-treated sediment cores revealed that a steep $\mathrm{Cd}$ diffusion gradient was established, with $\mathrm{Cd}$ concentrations being elevated in the top 3 and $4 \mathrm{~cm}$ for the sediment and pore water compartments respectively. The pore water phase within the sedimentary matrix showed the greatest changes in response to $\mathrm{Cd}$ input and formed the most sensitive indicator of changes in ambient Cd levels.

Cd can exist as different chemical species in natural waters (Raspor 1980). The dissolved metal content may be present as hydrated ions, complexed with inorganic ligands such as chloro, carbonato and hydroxo complexes, or chelated in rather stable and inert complexes with organic ligands such as amino, fulvic, humic and nucleic acids, proteins, thionines, and chelators of anthropogenic origin (e.g EDTA, NTA). Metals can also be associated with colloidal particles or occur adsorbed to or incorporated in suspended particulate matter or sediments. Many authors have suggested that the possible binding and adsorption mechanisms of $\mathrm{Cd}$ to the different geochemical phases in the sediment, such as hydrous metal oxides, clays and organic material, is important (Oakley et al. 1981, Davies-Colley et al. 1984). This study examined the fate and distribution of $\mathrm{Cd}$ additions combined with additions of different organic materials within the sedimentary matrix. The addition of 3 different types of organic material (fibres, sewage and benthic algae) resulted in diverse changes to the $\mathrm{Cd}$ distribution and concentration within the sediment/pore water matrix.
The fibre treatment in this study was derived from the pulp production industry; the fibres were rich in the coloured, refractory polyphenolic compounds known as humics, fulvics and tannins. These compounds result from the chemical polymerization and microbial decomposition and synthesis of plant components such as lignin. The particulate content of the fibre treatment used was low, most of the organic carbon was in the dissolved form, and at the termination of the experiment the overlying water phase was noticeably discoloured, suggesting the presence of organics such as fulvics and humics.

Fulvic acids, as mentioned above, significantly increase the metal-binding capacity of the overlying water, as they are the most hydrophilic of humic substances. This is illustrated in a study by Green et al. (1993) in which the toxicity of Cd to meiobenthic copepods was examined; they proposed that the oxygencontaining functional groups of fulvic acid associate with transitional metals such as $\mathrm{Cd}$ to form nonbioavailable complexes. Riffaldi et al. (1983) also found a positive correlation between $\mathrm{Cd}$ retention capacity and fulvic acid content, despite the lack of correlation with total carbon content, and proposed that the sorptive mechanism of $\mathrm{Cd}$ by fulvic acid may be due to the formation of salts or complexes involving the occurrence of both acidic carboxyl and phenolic hydroxyl groups. Therefore, in the present study, the possibility that $\mathrm{Cd}$ complexed with the fibre treatment and was bound in suspension in the water phase is convincing. It is important to note that $\mathrm{Cd}$ bound within such stable complexes is not detectable by the ASV method used to determine $\mathrm{Cd}$ in the outflowing sea water, and therefore the retention data may have been overestimated

The organic additions of sewage and algae had similar effects on the partitioning of $\mathrm{Cd}$, but their effects were quite different from that of the fibres. This is clear from the depth distribution of $\mathrm{Cd}$, where sediment $\mathrm{Cd}$ concentrations increased in the surface $2 \mathrm{~cm}$ of sediment and corresponding pore water concentrations decreased compared with the Cd control, implying a net movement of $\mathrm{Cd}$ from the pore water to the sediment phase. The strongest effect of both the sewage and algal treaments on Cd partitioning was a highly significant decrease in pore water $\mathrm{Cd}$ concentrations under high organic dosage treatments. A corresponding dosage response with increased sediment $\mathrm{Cd}$ concentrations was shown between the low and high sewage treatments; however, the 2 dosage levels of algae maintained similar sediment $\mathrm{Cd}$ concentrations.

It is well known that benthic algae have great potential to accumulate and concentrate heavy metals to levels much higher than ambient concentrations. Non-living algae, including the freeze-dried material used in 
this study, also have this accumulating ability (Zhoa et al. 1994). Therefore, the increased particulate sediment $\mathrm{Cd}$ concentrations in this study are not too surprising. However, it is significant that increased algae enrichment resulted in corresponding reductions in pore water $\mathrm{Cd}$ concentrations, i.e. to approximately half of the absolute $\mathrm{Cd}$ control concentration at high organic dosage levels. This same trend was observed for the sewage treatment. Reports have shown that sewage also has the ability to change the metal-binding capacity of the sediment (Riffaldi et al. 1983, Thomson et al. 1984) and that slight enrichment of sediment by sewage sludge was more effective than the fine fraction of natural sediments in binding $\mathrm{Cd}$ and reducing toxicity. This is in accordance with the results from the present study in which organic enrichment by sewage sludge increased sediment $\mathrm{Cd}$ and greatly reduced Cd pore water concentrations. The association mechanism of $\mathrm{Cd}$ to the sewage material has not been completely established. However, Swartz et al. (1985) noted that the binding capacity of such sewage materials is determined qualitatively by organic and inorganic composition, and not quantitatively by total volatile solids; this was confirmed by Riffaldi et al. (1983), who found a significant correlation between $\mathrm{Cd}$ retention capacity and fulvic acid content. Interestingly, they found no correlation between $\mathrm{Cd}$ retention and total organic carbon content, which may also explain the different fate and partitioning of $\mathrm{Cd}$ in this present study under conditions of different organic enrichment, with constant organic carbon contents. Results from the present study indicated that Cd partitioning in the sedimentary matrix is therefore dependent on the 'type' of organic material, and further consideration must be given to the particulate and dissolved nature of the organic fractions.

In this study, sulfide ion activity increased significantly under conditions of organic enrichment by both algal doses and high dosage levels of sewage, thereby increasing the potential binding capacity of $\mathrm{Cd}$ in the sedimentary matrix. Trace metal ions such as $\mathrm{Cd}^{2+}$ can react with $\mathrm{HS}^{-}$to form sulfides less soluble than FeS according to the following reaction:

$$
\mathrm{M}^{2+}+\mathrm{HS}^{-} \rightarrow \mathrm{MS}(\mathrm{s})+\mathrm{H}^{+}
$$

where $M$ is the trace metal and MS(s) represents trace metal sulfides (Hare et al. 1994). Studies have demonstrated that acid volatile sulfides (AVS) in anaerobic marine sediments may be a key binding phase controlling Cd pore water concentrations (Ankley et al. 1991, Di Toro et al. 1991). Therefore, the binding of Cd to both increased sulfide ions and the organic material itself presents the most likely mechanisms behind the observed increase in sediment particulate-bound $\mathrm{Cd}$ and a corresponding decrease in pore water $\mathrm{Cd}$ con- centrations under conditions of organic enrichment in this study.

The results of the Cd partitioning between the sediment and pore water phases can be compared to the following equilibrium partitioning model for sediment contaminants normalized to organic carbon (De Witt et al. 1992):

$$
C_{1 w}=C_{s} /\left(K_{O C}\right)\left(f_{O C}\right)
$$

where $C_{i w}=C d$ concentration in interstitial water (mg $\left.\mathrm{l}^{-1}\right), C_{\mathrm{s}}=\mathrm{Cd}$ concentration in the sediment $\left(\mu \mathrm{g} \mathrm{g}^{-1}\right)$, $K_{o c}=$ octanol/water partition coefficient for $\mathrm{Cd}, f_{o c}=$ total organic carbon (OC) content in sediment expressed as fractional mass ( $\mathrm{kg} \mathrm{OC} \mathrm{kg}^{-1} \mathrm{DW}$ ). Assuming $K_{\text {oc }}$ to be constant between all treatments for $\mathrm{Cd}$ $\left(K_{\mathrm{oc}}\right.$ for $\mathrm{Cd}=64000$; Webster \& Ridgway 1994), a reduction in pore water contaminants would be expected after increases in organic quantity, as seen in this study. However, the differences observed in the melal partitioning by organic 'quality' (type) treat. ments is not reflected by this general contaminant equilibrium partitioning model. Therefore, caution should be taken with such partitioning and AVS mod. els that are attractive in their simplicity as predictors of physical and biological effects (Hare et al. 1994).

The significant reduction in $\mathrm{Cd}$ pore water concentrations subsequent to all organic enrichment treatments in this study has important implications for the toxicity of this metal in the environment, since recent research has emphasised the direct relationship between metal concentration in interstitial water and sediment toxicity (Swartz et al. 1985, Kemp \& Swartz 1988, Landrum 1989, Green et al. 1993). Results from studies investigating the exposure routes of $\mathrm{Cd}$ to benthic fauna have indicated that, in whole sediments, the pore water phase $\mathrm{Cd}$ is the primary source of acute toxicity, as sediment associated $\mathrm{Cd}$ contributes negligible effects, and this is illustrated by the concentration/ mortality curve for metals that correlates better with pore water than bulk sediment concentrations (Swartz et al. 1985, Kemp \& Swartz 1988, Di Toro et al. 1991).

Therefore, if the pore water phase does in fact present the primary exposure route of $\mathrm{Cd}$ to benthic organisms and organic enrichment treatments have significantly reduced $\mathrm{Cd}$ pore water concentrations, a corresponding decrease in $\mathrm{Cd}$ bioaccumulation would be expected and will be discussed in the following section.

\section{Cd bioaccumulation}

Bioaccumulation of $\mathrm{Cd}$ in the 2 amphiurid species, Amphiura filiformis and A. chiajei, showed significant variation between the different organic regimes, with 
individuals containing less $\mathrm{Cd}$ in the fibre treatment and more in the algae treatment and showing no significant differences in the sewage treatment with respect to the $\mathrm{Cd}$ control.

It may be considered that these observed differences in Cd concentrations between organic enrichment treatments may reflect the feeding habits, life history strategies and also metabolism of the 2 amphiurid species. Amphiura filiformis and Amphiura chiajei are 2 species of burrowing ophiuroid brittle-stars of the family Amphiuridae and comprise the dominant or co-dominant components of many benthic communities (Buchanan 1964, Bouwman \& Keegan 1983). They live in semi-permanent burrows several centimetres below the sediment surface and extend their arms to feed.

The uptake route of $\mathrm{Cd}$, via either the interstitial pore water or the food source, may explain the observed differences in Cd bioaccumulation in response to organic enrichment quality. The elevated tissue $\mathrm{Cd}$ concentrations in both amphiurid species for the algal treatment, with respect to the $\mathrm{Cd}$ control, contradicts the hypothesis that the interstitial water forms the primary route of Cd uptake. In contrast, the process of selective feeding on food sources associated with $\mathrm{Cd}$ may account for the high Cd concentrations in organisms from 'high quality' organic treatments such as algae.

Under conditions of additional $\mathrm{Cd}$ only, the bivalve Abra alba accumulated more Cd than it did under conditions of $\mathrm{Cd}$ addition and organic enrichment, and the magnitude of this increase, being 9-fold, was much greater than for both amphiurid species. This is not perhaps surprising as molluscs are known to concentrate toxic metals to a considerable degree over environmental levels (Bryan 1971), and this molluscan capacity to magnify and integrate aquatic pollutants has played a key role in monitoring environmental quality. For $A$. alba the 3 different 'types' of organic enrichment treatments resulted in a gradient of increasing Cd bioaccumulation in the sequence: fibre < sewage < algae enrichment. $A$. alba is a bivalve species common in fine sediments of the littoral fringe and is of great ecological interest on account of its wide biogeographical distribution and high densities (Hily \& Le Bris 1983). It is a deposit feeding bivalve up to ca $12 \mathrm{~mm}$ in length that burrows 3 to $5 \mathrm{~cm}$ in depth and, from below the surface, sucks up the thin top sediment layer by movement of its long siphons, which are 4 to $5 \mathrm{~cm}$ in length (Amouroux et al. 1989). Because it is protected by a thin shell, the most obvious route of Cd uptake would be via its food source, the particulate sediment. Sediment $\mathrm{Cd}$, which includes sedimented particulate organic additions associated with $\mathrm{Cd}$, was lower in concentration in the fibre treatment relative to the Cd control, hence suggesting that the particulate sediment which provides a food source to this deposit feeding bivalve may be a primary uptake route of $\mathrm{Cd}$
The growth of Nereis diversicolor was included in this study as a biological measure or assay of the organic matter or food 'quality'. $N$. diversicolor was selected as an experimental animal due to its wide biogeographical distribution and also on account of its diverse feeding strategies and infaunal nature. The growth response of $N$. diversicolor indicated a food limited system for this species due to a loss in biomass in both control treatments $(-\mathrm{Cd}$ and $+\mathrm{Cd})$ and in the fibre treatments. The sewage and algal organic enrichments provided conditions for increased growth and showed a distinct dose dependent response to food supply. Thus a positive growth trend occurred with respect to the 'quality' or 'non-refractory nature' of the organic material, from a decrease in individual biomass in the fibre treatment to up to $80 \%$ growth under conditions of algal enrichment.

A similar pattern is clear from the dose-response curves of $\mathrm{Cd}$ bioaccumulation in both amphiurid species and Abra alba in response to the 3 types of organic material. A comparison of Figs. $4 \& 5$ shows direct concordance between the effect of organic source (type) on polychaete growth and Cd bioaccumulation, indicating that the higher qualities of 'food' lead to increased bioaccumulation of $\mathrm{Cd}$. This is in contrast to an expected decrease in Cd bioavailability for all species in all organic enrichment treatments, with respect to the Cd control, if the pore water was the major route of $\mathrm{Cd}$ uptake. However, it should be noted that, as $\mathrm{Cd}$ pore water concentrations decreased from low to high organic enrichment, $\mathrm{Cd}$ bioaccumulation in both amphiurid species decreased marginally in accordance with Cd uptake via the pore water phase.

In conclusion, the above points suggest that pore water may not be the only important exposure route of $\mathrm{Cd}$ to these benthic organisms. The organic 'quality' or a related parameter forms a most significant factor in determining the bioaccumulation of $\mathrm{Cd}$ to the benthic organisms examined, and it is proposed that further insights into the bioavailability of heavy metals in marine environments may involve investigating the physiological conditions surrounding the biological absorption of metals. This study therefore demonstrates the need for a greater understanding of the interactive processes between trace metal partitioning and different 'types' of anthropogenic and natural sources of organic enrichment.

Acknowledgements. I gratefully acknowledge the financial support of The European Commission within the framework of the international 'Access to Large-Scale Facility Programme' and NIVA for providing facilities at Solbergstrand Marine Station, Oslofjord. My sincere thanks to Einar Johannessen and Erik Bjernbom who provided technical assistance, and also Prof. M. Abdullah and Arne Pettersen at Oslo Uni- 
versity for assistance with pore water analysis. Finally, my special thanks to Drs Mike Ireland and Tom Forbes for invaluable advice and helpful discussions.

\section{LITERATURE CITED}

Abdullah MI, Reusch Berg B, Klimek R (1976) The determination of zinc, cadmium, lead and copper in a single seawater sample by differential pulse anodic stripping voltammetry. Analyt Chim Acta 84:307-317

Aller RC (1983) The importance of the diffusive permeability of animal burrow linings in determining marine sediment chemistry. J Mar Res 41:299-322

Aller RC, Yingst JY (1985) Effects of the marine deposit feeders Heteromastus filiformis (Polychaeta), Macoma balthica ( $\mathrm{Bi}-$ valvia) and Tellina texana (Bivalvia) on averaged sedimentary solute transport, reaction rates, and microbial distributions. J Mar Res 43:615-645

Amouroux JM, Grémare A, Amouroux J (1989) Modelling consumption and assimilation in Abra alba (Mollusca, Bivalvia). Mar Ecol Prog Ser 51:87-97

Ankley GT, Phipps GL, Leonard EN, Benoit DA, Mattson VR, Kosian PA, Cotter AM, Dierkes JR, Hansen DJ, Mahony JD (1991) Acid-volatile sulfide as a factor mediating cadmium and nickel bioavailability in contaminated sediments. Environ Toxicol Chem 10:1299-1307

Bouwman T, Keegan BF (1983) Field survey of the occurrence and significance of regeneration in Amphura filiformis (Echinodermata: Ophiuroidea) from Galway Bay, west coast of Ireland. Mar Biol 74:65-71

Bryan GW (1971) The effects of heavy metals (other than mercury) on marine and estuarine organisms. Proc R Soc Lond B $177: 389-410$

Buchanan JB (1964) A comparative study of some features of the biology of Amphiura filiformis and Amphiura chiajei (Ophiuroidea) considered in relation to their distribution. J Mar Biol Ass UK 44:565-576

Davies-Colley RJ, Nelson PO, Williamson KJ (1984) Copper and cadmium uptake by estuarine sedimentary phases. Environ Sci Technol 18:491-499

De Witt TH, Ozretich RJ, Swartz RC, Lamberson JO, Schults DW, Ditsworth GR, Jones JKP, Hoselton L, Smith LM (1992) The influence of organic matter quality on the toxicology and partitioning of sediment-associated fluoranthene. Environ Toxicol Chem 11:197-208

Di Toro DM, Mahony JD, Hansen KJ, Scott KJ, Hicks MB, Mayr SM, Redmond MS (1990) Toxicity of cadmium in sediments: the role of acid volatile sulfide. Environ Toxicol Chem 9:1487-1502

Di Toro DM, Zarba CS, Hansen DJ, Berry WJ, Swartz RC, Cowan CE, Pavlou SP, Allen HE, Thomas NA, Paquin PR (1991) Technical basis for establishing sediment quality criteria for nonionic organic chemicals using equilibrium partitioning. Environ Toxicol Chem 10:1541-1583

Forstner U (1980) Cadmium in polluted sediments. In: Nriagu JO (ed) Cadmium in the environment. John Wiley and Sons Ltd, New York, p 305-363

George SG, Viarengo A (1984) An integration of current knowledge of the uptake, metabolism and intracellular control of heavy metals in mussels. In: Vernberg FJ, Thurberg FP, Calabrese A, Vernberg WB (eds) Marine pollution and physiology: recent advances. University of South Carolina Press, Columbia, p 125-144

Grassle JF, Grassle JP, Brown-Leger LS, Petrecca RF, Copley NJ (1985) Subtidal macrobenthos of Narragansett Bay. Field and mesocosm studies of the effects of eutrophica- tion and organic input on benthic populations. In: Gray JS, Christiansen ME (eds) Marine biology of the polar regions and effects of stress on marine organisms. John Wiley and Sons Ltd, Chichester, p 421-434

Green AS, Chandler GT, Blood ER (1993) Aqueous-, pore water-, and sediment-phase cadmium: toxicity relationships for a meiobenthic copepod. Environ Toxicol Chem 12:1497-1506

Grémare A, Amouroux JM, Cahet $G$, Charles $F$, Vétion $G$ (1991) Utilization of a fumigated sediment by two benthic deposit-feeders: Abra alba (Mollusca: Bivalvia) and Eupolymnia nebulosa (Annelida: Polychaeta). Mar Biol 109:469-477

Hare L, Carignan R, Huerta-Diaz MA. (1994) A field study of metal toxicity and accumulation by benthic invertebrates; implications for the acld-volatile sulfide model (AVS) model. Lumnol Oceanogr 39(7):1653-1668

Hily C, Le Bris H (1983) Dynamics of an Abra alba population (Bivalva-Scobiculariidae) in the Bay of Brest. Estuar Coast Shelf Sci 19:463-475

Ibanez F, Dauvin JC (1988) Long-term changes (1977-1987) in a muddy fine sand Abra alba-Melinna palmata community from the western English Channel: multivariate timeseries analysis. Mar Ecol Prog Ser 49:65-81

Jonsson P, Broman D, Gunnarsson $J$, Olsson $M$, Rosenberg R (1993) Interactive processes between eutrophication and pollutant dynamics in the aquatic environment. A preliminary research programme. Swedish Protection Agency, Solna

Kemp PF, Swartz RC (1988) Acute toxicity of interstitial and particle-bound cadmium to a marine infaunal copepod. Mar Environ Res 26:135-153

Landrum PF (1989) Bioavailability and toxicokinetics of polyaromatic hydrocarbons sorbed to sediments for the amph1pod Pontoporeia hoyi. Environ Sci Technol 23:588-595

Lithner G, Borg H, Gnmás U, Gotheberg A, Neumann $G$, Wrådhe H (1990) Current status of the Baltic Sea-estimating the load of metals to the Baltic Sea. Ambio Spec Rep $7: 7-9$

Marigómez I, Ireland MP, Angulo E (1990) Correlation of cadmium shell-weight index with environmental stress indicators at the cellular and organismic levels in Littorina littorea. Mar Ecol Prog Ser 67:171-176

Munday BW, Keegan BF (1992) Population dynamics of Amphiura chiajei (Echinodermata: Ophiuroidea) in Killary harbour, on the west coast of Ireland. Mar Biol 114: 595-605

Oakley SM, Nelson PO, Williamson KJ (1981) Model of tracemetal partitioning in marine sediments. Environ Sci Technol 15:474-480

Olsson M, Jensen S (1975) Pike as test organism for mercury, DDT and PCB pollution. A study of the contamination in the Stockholm archipelago. Inst Freshwat Res Drottningholm Rep 54:83-106

Pearson TH, Rosenberg R (1976) A comparative study of the effects on the marine environment of wastes from cellulose industries in Scotland and Sweden. Ambio 5:77-79

Phillips DJH (1977) The use of biological indicator organisms to monitor metal pollution in marine and estuarine environments-a review. Environ Pollut 1.3:281-317

Raspor B (1980) Distribution and speciation of cadmium in natural waters. In: Nriagu JO (ed) Cadmium in the enviromment. John Wiley and Sons Ltd, New York, p 147-236

Riffaldi R, Levi-Minza R, Saviozzi A, Tropea M (1983) Sorption and release of cadmium by some sewage sludges. J Environ Qual 12:253-256

Riisgard HU (1994) Filter-feeding in the polychaete Nereis 
diversicolor a review. Neth J Aquat Ecol 28(3-4):453-458

Roberts DF, Elliott M, Read PA (1986) Cadmium contamination, accumulation and some effects of this metal in mussels from a polluted marine environment. Mar Environ Res 18:165-183

Sköld M, Loo LO, Rosenberg R (1994) Production, dynamics and demography of an Amphiura filiformis population. Mar Ecol Prog Ser 103:81-90

Sokal RR, Rohlf FJ (1981) Biometry, 2nd edn. WH Freeman, San Francisco

Swartz RC, Ditsworth GR, Schults DW, Lamberson JO (1985) Sediment toxicity to a marine infaunal amphipod: cadmium and its interaction with sewage sludge. Mar Environ Res 18:133-153

Taylor WD, Carey JH, Lean DRS, McQueen DJ (1991) Organochlorine concentrations in the plankton of lakes in southern Ontario and their relationship to plankton biomass. Can J Fish Aquat Sci 48:1960-1966

Thomson EA, Luoma SN, Johansson CE, Cain DJ (1984) Com-

This article was submitted to the editor parıson of sediments and organisms in identifying sources of biologically available trace metal contamination. Wat Res 18:755-765

Underwood AJ (1981) Techniques of analysis of variance in experimental marine biology and ecology. Mar Biol Ann Rev 19:513-605

Viarengo A, Palmero S, Zancicchi G, Capelli R, Vaissiere R, Orunesu M (1985) Role of metallothioneins in $\mathrm{Cu}$ and $\mathrm{Cd}$ accumulation and elimination in the gill and digestive gland cells of Mytilus galloprovincialis Lam. Mar Environ Res 16:23-26

Webster J, Ridgway $I$ (1994) The application of the equilıbrum partitioning approach for establishing sediment quality criteria at two UK sea disposal and outfall sites. Mar Pollut Bull 28(11):653-661

Zhoa Y, Hao Y, Ramelow GJ (1994) Evaluation of treatment techniques for increasing the uptake of metal ions from solution by nonliving seaweed algal biomass. Environ Monit Assess 33:61-70

Manuscript first received: May 31, 1996

Revised version accepted: October 10,1996 